DOI https://doi.org/10.18551/rjoas.2018-06.12

\title{
COMMUNITY-BASED POVERTY ALLEVIATION USING PARTICIPATORY RURAL APPRAISAL
}

\author{
Muhsin Ahmad* \\ Faculty of Industrial Engineering, Universitas Pembangunan Nasional, Indonesia \\ Darpito Surpiko Hapsoro, Siswanti Yuni \\ Faculty of Economy, Universitas Pembangunan Nasional, Indonesia \\ *E-mail: ahmad.muhsin@upnyk.ac.id \\ ORCID: 0000-0003-2457-268x
}

\begin{abstract}
People living in mountainous and rural areas are more vulnerable to living in poverty due to many factors. This is shown by the high poverty rate in the BPS data and GAKIN (Poor Family) list. Most farmers and laborers are people living in rural areas. The financial condition of the farmers and laborers is considered worse than other communities (the more poor of the poor). Poverty alleviation and community empowerment programs set by the government for the past decades are proven to be not entirely successful and not as expected, followed by many failures in implementing the programs. It was because the empowerment model was Top Down, from the government to the people with pre-determined criteria which are standard and not based on situations, conditions, and occupations of the program target communities. This study aimed to get a community empowerment model which is right on target, based on criteria approach directly explored from the program target communities. The resulting Participatory Rural Appraisal method produces village social condition or village map which shows the potentials, problems, opportunities, and strengths of the community to be the basis for problem solving, program planning, achievement and joint monitoring consistent with their potential and ability.
\end{abstract}

\section{KEY WORDS}

Participatory rural appraisal, the poor, village map, poverty.

People living in mountainous and rural areas are more vulnerable to living in poverty due to many factors. This is shown by the high poverty rate in the BPS data and GAKIN (Poor Family) list. Most farmers and laborers are people living in rural areas. The financial condition of the farmers and laborers is considered worse than other communities (the more poor of the poor).

Community empowerment is a process to develop and strengthen people's ability to enable them to always be able to be involved in the dynamic development process, so that they can solve their problems and make decision independently and adjust to changes in their environment. There have been many community empowerment programs by the government to erase discrepancy and poverty in rural areas which are also remote and mountainous areas. Some of the government programs for poverty alleviation are Presidential Instruction for Disadvantage Village Program (IDT), Family Welfare Program, Disadvantage Village Supporting Infrastructure Development Program (P3DT), Sub-district Development Program (PPK), and Social Safety Net Program (JPS), Village and urban PNPM.

Some of the government programs specifically directed to the target communities area Coastal Community Empowerment Program (PEMP) and Small-Scale Capture Fishery Business Development Program (PUPTSK). However, generally, the programs don't improve the welfare of rural people. Once of the reasons for the lack of success of the government programs to alleviate poverty is because the policies are top down. The present study aimed to create awareness among people on the condition, ability, and involvement to actively 
respond to changes, through the people's perspective, using participative activities. PRA is a way to formulate appropriate community empowerment policy which is in accordance with local issues, based on aspiration and geographical condition and people.

The initial hypothesis based on field observation was people had varying conditions and people in rural areas tended to be unable to cope with environmental changes due to the entry of industries into the areas. If this continues, there may be economic inequality and disparity, impacting people's social life. Moreover, there are still many poor people who are recorded as GAKIN (Poor Family), receive RASKIN (Rice for the Poor), and request SKTM (Certificate of Poverty), and or own JAMKESMAS (Public Health Insurance).

A study in Tunisia on 200 poor families show that social security program to solve poverty fails to fulfill needs, and people have poor impression on services which use social security, including health, education, and housing (Khemili \& Belloumi, 2018). Poverty is a condition influenced by many factors; therefore it's not enough to merely give financial aids to solve it. Opening economic opportunities, developing strengths and empowering potentials are required.

Differences in income and public welfare which have been studied in China, especially in rural areas show that to equalize income, there should be appropriate policies and developments which are in accordance with the needs of regional and provincial areas $(\mathrm{Li}$, Long, Tu, \& Wang, 2015). It's important to eradicate poverty because it's a sign of poor basic consumption needs which can affect status, social relation, and spirituality because the poor tend to doubt God, cultivate jealousy, envy, blaming, lack of gratitude, gluttony, greed and other bad behaviors (Derdziuk, 2015).

Participative approach method is used to gain information on people's challenges and find solutions for difficulties (Getchell et al., 2002). A study in Africa shows that losing cattle, such as cow, can affect farmer's finance. Therefore participative approach is required so that farmer community is open to necropsy training program to reduce animal death (Makgatho, McCrindle, \& Owen, 2005).

The current community empowerment methods aren't always successful and sometimes fail because they don't start with study on the appropriate method for empowering the community of certain region. A worse outcome is government's Poverty Alleviation Programs are viewed a financial aids which area ready to be consumed and must be received by people, so a lot of people register as poor people to get the aids.

The models in effect have the same patterns in cash and non-cash aids, while the people vary and have specific characteristics. The village community empowerment programs are technical with simple criteria, e.g. based on wealth. The condition of underdeveloped communities should be viewed holistically and systemically. Factors which also affect people's condition vary, and people know their community better than anyone else. In 1990, an idea emerged on welfare by emphasizing solving the problem of people's awareness on their condition and strength. For that end, a participative analysis is required, i.e. Participatory Rural Appraisal (PRA). PRA is an interactive process which involves people as the program targets, with self-knowledge as the foundation because they know their personal condition better than anyone. Therefore, poverty alleviation program should be arranged with the target communities. PRA is packaged as Focus Group Discussion (FGD) to get participative approach (Uddin \& Anjuman, 2013).

Today, most development activities focus on sustainable development, which is development which is qualified today without disturbing future generation's utilization. Basically, sustainable development is related to environmental, social, and economic initiations. Therefore, people's participation has a key role in the effective strategy for sustainable development (Koralagama, Wijeratne, \& De Silva, 2007).

This makes people less productive but more consumptive and weaker. The approach in the present study was Participatory Rural Appraisal which was formulating community empowerment model so that people could develop their own abilities to solve their problems and make decisions independently. The present study describes some topics on the process of community empowerment, i.e.: power, accessibility to resources, and accommodating environment. PRA technique is focused on spatial, temporal, socio-economic and spatio- 
temporal aspects to identify and determine the main problem and obstacle of development (Castelli \& Bresci, 2017). The principles used in PRA are learning directly from people, equalizing inequality, optimizing role, awareness and personal responsibility (Castelli \& Bresci, 2017). PRA is useful in identifying condition, requirement, problem and opportunity of developing potentials and overall efficiency of rural area (Indrizal, 2014).

This method was expected to make people gain solution to anticipate changes in the society and environment and enable people to develop to fulfill their needs, so that the community develop independently, sustainable, and continuously.

\section{METHODS OF RESEARCH}

The study was performed in Srimulyo Village, Piyungan Sub-district, Bantul Regency. Srimulyo Village was selected because the community is at the line of poverty but actually has undeveloped potentials. Moreover, Srimulyo area has been established by the government to be a prospective industrial area, so people must be ready for changes.

The research instruments included: Camera to document activities and stationeries to record activity data. Research material - The research materials included: Plano, paper to record activity result. The data used in this study was primary data and secondary data. Primary data was obtained directly from observation on objects in Srimulyo, whether the community or geographical condition. The secondary data was obtained from data provided by Srimulyo village government and BPS. The research object was the Group of the Poor in Srimulyo Village, Piyungan, Bantul, Yogyakarta, to obtain effective community empowerment model based on criteria directly obtained from the target community.

Data Processing. The sampling in the present study used purposive sampling technique. The community which became the sample of the present study was the women's group in Srimulyo Village. The community was divided into several groups and each group had discussion to collect data consistent with the technique in use and the result was presented to be approved together, so the conclusion was a joint decision. The research result data was analyzed qualitatively. To determine the problem and development, SWOT method was used qualitatively in Table 1.

Table 1 - SWOT for factor determination

\begin{tabular}{|c|c|c|}
\hline $\begin{array}{l}\text { Internal Factor } \\
\text { External Factor }\end{array}$ & Strengths (S) & Weakness (W) \\
\hline & SO Strategy: & WO Strategy: \\
\hline Opportunities (O) & $\begin{array}{l}\text { Strategy established based on utilization of all } \\
\text { strengths to overtake and utilize opportunities } \\
\text { as much as possible }\end{array}$ & $\begin{array}{c}\text { Strategy established based on utilization of } \\
\text { existing opportunities by minimizing } \\
\text { weaknesses }\end{array}$ \\
\hline & ST Strategy: & WT Strategy: \\
\hline Threats $(T)$ & $\begin{array}{l}\text { Strategy established based on community's } \\
\text { strengths to overcome threats }\end{array}$ & $\begin{array}{l}\text { Strategy established based on defensive } \\
\text { and attempts to minimize existing } \\
\text { weaknesses and avoid threats }\end{array}$ \\
\hline
\end{tabular}

\section{RESULTS AND DISCUSSION}

Making Village Data. Data collection by Focus Group Discussion (FGD) produced a conclusion that generally in the village there are more women's groups than other groups. Women's participation in their groups tended to be high. However, in groups mixed with men, women's participation was lower due to the view that technical or environmental field belong to men, so women chose to be passive. Education/understanding on politics and citizenship were provided for women beside business counseling. The success rate showed in the participation of (counseled) women in meetings at higher levels, e.g. hamlet, village, and regency. Beside education for women, men also needed understanding on their roles and the importance of listening to women's voices. It's because women have to bear 
psychological burden if they're in a group of men and women but their opinions aren't listened to in the forum.

Tracing Village History. Srimulyo Village is a combination of 4 (four) urban villages, i.e. Bintaran Urban Village, Payak Urban Village, Sandeyan Urban Village, and Jolotirto Urban Village. At first, Bintaran Urban Village was governed by Mr. Dullah, Payak Urban Village by Cokro Arjo, Sandeyan Urban Village by Dhemo/Khunting, and Jolotirto Urban Village by Wongso Sediro. They were combined after the independence, on 10 October 1946, based on the Law of RI no 13 of 1946 on removal of perdikan villages which were villages which were Dutch called "Virjedesa".

Virjedesa then decided to unite into Srimulyo Village. The urban villages became "Kring", i.e. Kring Bintaran, Kring Payak, Kring Sandeyan, and Kring Jolosutro. Later, in 1964, the urban villages and hamlets in them joined together to be Srimulyo Village. The division of Kring wasn't regulated by government administration but was very useful in supporting the operational activities of Srimulyo village government, especially since the emotional bonds of the community was still strong, supported by close geographical location, similar regional potential, and close social cultural activities in one kring. The first urban village head of Srimulyo was Cokro Subroto. The area of Srimulyo Village consisted of 22 hamlets and 119 RT.

Chart of Occupation. Srimulyo Village is located in Piyungan Sub-district, Bantul Regency, Special Region of Yogyakarta Province. Srimulyo Village has a very strategic location between two other villages in Piyungan Sub-district and is the gate to Gunungkidul Regency which has tourism potential. Beside the location, Srimulyo Village has potentials to be an independent village which sets an example for other villages in Yogyakarta or Indonesia. The potentials are supported by rich biological resources across Srimulyo Village. Natural resources potentials in Srimulyo Village can be processed and managed further to produce food and tourist attractions, all of which play very important roles to developing Srimulyo Village in particular and Bantul Regency in general.

Table 2 - Occupation of Srimulyo Village Residents

\begin{tabular}{|c|c|c|c|c|c|c|c|c|}
\hline \multirow{2}{*}{ Time } & \multirow{2}{*}{ Employee } & \multirow{2}{*}{ Farmer } & \multicolumn{3}{|c|}{ Plantation } & \multicolumn{3}{|c|}{ Farms } \\
\hline & & & Yam & Nut & Guava & Chicken & Goat & Cow \\
\hline $2000-2005$ & * & *** & $* * *$ & ** & * & $\star * *$ & $* * *$ & $\star *$ \\
\hline $2006-2011$ & ** & ** & $* * *$ & ** & * & $\star \star *$ & $\star \star \star$ & ** \\
\hline $2112-2017$ & *** & ** & $* * *$ & ** & * & $* * *$ & $\star \star \star *$ & ** \\
\hline
\end{tabular}

Note: $-=$ None; ${ }^{*}=$ Few; ${ }^{* *}=$ Medium; ${ }^{* * *}=$ Many.

Significant changes happened after the earthquake which hit Bantul Regency in 2006 which destroyed houses and changed the function of agricultural lands. Most people chose to be employees for their livelihood.

Seasonal Calendar. Lands in Srimulyo Village designated to be agricultural lands, plantations, and moors have great potentials. The great land potentials of Srimulyo Village should be followed by management and optimization to gain optimum profit. The hamlet with the largest crop production land is Kaligatuk Hamlet which has $222.9 \mathrm{Ha}$ of land. Meanwhile, the smallest agricultural production land belongs to Payak Wetan Hamlet which has $5.9 \mathrm{Ha}$ of land. The lands are designated for agriculture and plantation in every hamlet. In Srimulyo, there are many cow and goat breeder groups.

Table 3 - Seasonal calendar of community's income

\begin{tabular}{|c|c|c|c|c|c|c|c|c|c|c|c|c|}
\hline \multirow{2}{*}{ Commodity } & \multicolumn{12}{|c|}{ Month } \\
\hline & Jan & Feb & Mar & Apr & May & Jun & Jul & Aug & Sep & Oct & Nov & Dec \\
\hline Rice & $x$ & $x$ & $x$ & & & & & & & $x$ & $x$ & $X$ \\
\hline Yam & $x$ & $x$ & $x$ & $x$ & $x$ & $x$ & $x$ & $x$ & $x$ & $x$ & $x$ & $x$ \\
\hline Nut & & & & $x$ & $x$ & $x$ & $x$ & $x$ & $x$ & & & \\
\hline Guava & $x$ & $x$ & $x$ & $x$ & & & & & & $x$ & $x$ & $x$ \\
\hline
\end{tabular}

Note: $x=$ existing. 
The data shows the harvest time of the villagers' agricultural/plantation products, indicating the time required by laborers to harvest them. Agricultural and plantation products are affected by water or rainfall.

Village Sketch. The village sketch shows that plantations/agricultural lands surround the village. Srimulyo Village is composed of highland and mountainous areas, but also has big rivers to ensure the availability of water for agriculture in lowland.

Institutional Review. In Srimulyo Village, there are several institutions which affect the village community, e.g. PKK (Family Welfare Movement), Karangtaruna (youth organization), LPPMD (Institute for Democratic Research and Community Service), BMD (Regional Property), BUMDES (Village-owned Enterprise), LINMAS (Community Protectors), Village TPK (Activity Management Team) and Posyandu (Integrated Service Post), as well as relations among the institutions.

Identification of Potential and Problem. Identification is a process of collecting information or data on anything required by researcher. The purpose of identification was providing information on the actual condition of the village in terms of various observation aspects, whether strengths or weaknesses. Problem identification was performed by participation in each community. Identification was performed in group meeting using Participatory Rural Appraisal (PRA) technique. Any potential and problem is revealed in each group and approved by all groups.

The potentials of the community in Srimulyo Village are:

- The number of people of productive age is quite high, $60 \%$ of total village population;

- It has large lands for agriculture/plantation, etc;

- There are public facilities, e.g. schools, mosque, village office, village meeting hall and community activity supports, such as paved road, electricity, and irrigation;

- There are community institutions and groups, e.g. PKK, Karang Taruna, LPMD (Institute for Rural Community Empowerment), Puskesmas (Public Health Center);

- There are institutions which aren't optimally utilized, e.g. PPL (Election Monitoring) and Farmer Group;

- There is Farmer Group;

- There is policy on industrialization in the village;

- The plantation products, e.g. yams, corns, and nuts, are adequate.

The problems faced by Srimulyo Village community are as follows:

- Limited educated and skilled human resources to manage local potentials;

- Poor incentive for processing innovation;

- Suboptimal guidance by related department;

- Suboptimal institutional activities and coordination with other related institutions;

- Limited IT mastery and network;

- Difficulty publicizing and promoting the region;

- Limited agricultural product processing technology;

- No business permits ownership.

Table 4 - SWOT analysis

\begin{tabular}{lll}
\hline & Strength (S) & Weakness (W) \\
\hline Opportunity (O) & $\begin{array}{l}\text { Using large land to produce business production } \\
\text { materials }\end{array}$ & $\begin{array}{l}\text { Minimizing lack of human resources by } \\
\text { requesting training and guidance }\end{array}$ \\
& $\begin{array}{l}\text { Usilizing natural potentials to open tourism site } \\
\text { Reducing problem with agricultural product } \\
\text { processing technology by using the networks } \\
\text { of departments and universities }\end{array}$ \\
Threat $(\mathrm{T})$ & $\begin{array}{l}\text { Using free IT access from the sub-district for } \\
\text { publicizing and promoting the village's potentials } \\
\text { Using the beauty of the area for tourism site and } \\
\text { to draw customers and investors to the village }\end{array}$ \\
\hline
\end{tabular}

Based on the resulting data, the potentials and problems above were separated into SWOT categories. Internal potentials are strengths, while external potentials are 
opportunities for the village communities. The problems are also separated into internal problems which are weaknesses and external problems which are threats.

Based on the result of the SWOT analysis, the following steps were formulated:

- The community has large land which can be optimized to make unique and special local products, e.g. Srimulyo Village unique souvenirs.

- The community can work with companies as material supplier

- Local product marketing can use information center and free internet access provided by the sub-district, as well as making website or online network.

- Processing technology for local products can be procured by working with related department and forming network with universities which are the centers of technology and science.

- Limited production capability due to lack of human resources should be minimized by requesting training and guiding

- Local products innovation and development are necessary to make local icons

- Legal support and production should be provided by registering brand or business license to the Ministry of Law and Human Rights.

\section{CONCLUSION}

Based on the result of Assessment of Community Potentials by Participative Approach in Srimulyo Village, Piyungan Sub-district, Bantul Regency, the following can be concluded:

- The potentials which can be developed are large land, agricultural and plantation products, natural potentials, industry, and related parties.

- The problems are lack of educated human resources, limited technology, promotion media, innovation, and legal protection

- Solutions for the problems are cultivating land to reinforce business production, utilizing natural potentials for tourism and bringing customers and investors, utilizing the sub-district's IT service for promotion media, working with related part for training and guiding, and working with universities to procure agricultural and plantation product processing technologies and business management.

\section{ACKNOWLEDGEMENTS}

The authors would like to thank the Institute for Research and Community Service (LPPM) of UPN "Veteran" Yogyakarta for facilitating this research in Cluster Research Scheme and providing financial support to produce this publication. The authors also would like to thank Amat Yani and facilitators, who helped community organizer.

\section{REFERENCES}

1. Castelli, G., \& Bresci, E. (2017). Participatory rural appraisal for Diagnostic Analysis of spate irrigation systems in Raya Valley, Ethiopia. Journal of Agriculture and Rural Development in the Tropics and Subtropics, 118(1), 129-139.

2. Derdziuk, A. (2015). Attitudes towards Poverty. The Journal of Theology, Education, Canon Law and Social Studies Inspired, 5(1), 155-175. https://doi.org/10.15633/pch.932

3. Getchell, J. K., Vatta, A. F., Motswatswe, P. W., Krecek, R. C., Moerane, R., Pell, A. N., Leshomo, S. (2002). Raising livestock in resource-poor communities of the North West Province of South Africa - a participatory rural appraisal study, 73, 177-184.

4. Indrizal, E. (2014). Pengkajian keadaan perdesaan secara partisipatif participatory rural appraisal (pra): suatu pengantar pengenalannya. JANTRO : Jurnal Antropologi : Isi-Isu Sosial Budaya, 15(2), 39-49. Retrieved from http://jurnalantropologi.fisip.unand.ac.id/

5. Khemili, H., \& Belloumi, M. (2018). Social Security and Fighting Poverty in Tunisia. Economies, 6(1), 12. https://doi.org/10.3390/economies6010012

6. Koralagama, D. N., Wijeratne, M., \& De Silva, W. N. (2007). Emergence of participatory 
rural appraisal (PRA) technique as a strategy towards sustainable development: A Sri Lankan experience. Journal of Agriculture and Rural Development in the Tropics and Subtropics, 108(2), 149-160.

7. Li, T., Long, H., Tu, S., \& Wang, Y. (2015). Analysis of income inequality based on income mobility for poverty alleviation in rural China. Sustainability (Switzerland), 7(12), 16362-16378. https://doi.org/10.3390/su71215821

8. Makgatho, C. N., McCrindle, C. M. E., \& Owen, J. H. (2005). Participatory rural appraisal to investigate constraints in reporting cattle mortalities in the Odi district of North West Province, South Africa. Journal of the South African Veterinary Association, 76(4), 209213.

9. Uddin, M. N., \& Anjuman, N. (2013). Participatory rural appraisal approaches: an overview and an exemplary application of focus group discussion in climate change adaptation and mitigation strategies. International Journal of Agricultural Research, Innovation and Technology, 3(2), 72-78. https://doi.org/10.3329/ijarit.v3i2.17848 